\title{
GLUT4 protein expression in obese and lean 12-month-old rats: insights from different types of data analysis
}

P.M. Seraphim,

M.T. Nunes and

U.F. Machado
Departamento de Fisiologia e Biofísica,

Instituto de Ciências Biomédicas, U niversidade de São Paulo,

São Paulo, SP, Brasil

\section{Correspondence}

U.F. Machado

Departamento de Fisiologia e

Biofísica, ICB, USP

Av. Prof. Lineu Prestes, 1524

05508-900 São Paulo, SP

Brasil

Fax: +55-11-818-7285

E-mail: ubiratan@ fisio.icb.usp.br

Research supported by FAPESP (No. 98/03514-3). P.M. Seraphim was the recipient of a $\mathrm{CNPq}$ fellowship (No. 142190/97-7).

Received December 6, 2000 Accepted June 18, 2001

\section{Abstract}

GLUT4 protein expression in white adipose tissue (WAT) and skeletal muscle (SM) was investigated in 2-month-old, 12-month-old spontaneously obese or 12-month-old calorie-restricted lean Wistar rats, by considering different parameters of analysis, such as tissue and body weight, and total protein yield of the tissue. In WAT, a $\sim 70 \%$ decrease was observed in plasma membrane and microsomal GLUT4 protein, expressed as $\mu \mathrm{g}$ protein or $\mathrm{g}$ tissue, in both 12-month-old obese and 12-month-old lean rats compared to 2-month-old rats. However, when plasma membrane and microsomal GLUT4 tissue contents were expressed as g body weight, they were the same. In SM, GLUT4 protein content, expressed as $\mu \mathrm{g}$ protein, was similar in 2-month-old and 12month-old obese rats, whereas it was reduced in 12-month-old obese rats, when expressed as $\mathrm{g}$ tissue or $\mathrm{g}$ body weight, which may play an important role in insulin resistance. Weight loss did not change the SM GLUT4 content. These results show that altered insulin sensitivity is accompanied by modulation of GLUT4 protein expression. However, the true role of WAT and SM GLUT4 contents in whole-body or tissue insulin sensitivity should be determined considering not only GLUT4 protein expression, but also the strong morphostructural changes in these tissues, which require different types of data analysis.

\section{Key words}

- Insulin resistance

- O besity

- Weight loss

- GLUT4 protein

\section{Introduction}

Obesity is a serious metabolic disorder whose prevalence has increased in the last 50 years. In general, obesity is accompanied by cardiovascular disease, hypertension, diabetes, and dyslipidemia, among other disorders, factors that increase the risk of mortality and morbidity (1). Since the report that a non-obese insulin-resistant population, referred to as "syndrome X", has the same risk factors for obesity, it has been considered that insulin resistance plays a key role in the physiopathology of obesity (2).

Several studies show that the impairment of glucose uptake by adipose tissues and muscles in non-insulin dependent diabetes mellitus, imposed hyperinsulinemia, fasting and refeeding, as well as in several models of genetically obese mice and rats, is related to GLUT4 alteration (3-6). However, this relationship is not fully clear, since several stud- 
ies do not relate insulin sensitivity and GLUT4 gene expression to protein tissue content $(5,7,8)$. Similarly, there are conflicting findings about weight loss, which is known to improve insulin sensitivity in the whole body both in humans $(9,10)$ and rodents (11), concerning the modulation of GLUT4 gene expression (10,12-14).

Obesity and weight loss promote strong morphostructural changes in insulin-sensitive tissues such as white adipose tissue (WAT) $(13,15)$ and skeletal muscle (SM) (16). For example, in adipose tissue, obesity increases tissue mass and decreases the relative total protein content, whereas weight loss acts inversely $(13,15)$. On this basis, tissue GLUT4 protein, assessed by Western blotting, can be expressed as $\mu \mathrm{g}$ protein subjected to electrophoresis, by whole tissue or body, or even by g tissue or body weight, each related to a specific parameter such as GLUT4 gene expression, glucose uptake related to whole tissue or body, or related to $g$ tissue or body weight (13). Thus, GLUT4 protein expression in obesity and weight loss should be analyzed carefully with respect to reference parameters.

The aim of the present study was to investigate the effect of obesity and weight loss on GLUT4 protein expression, and the possible role of tissue GLUT4 content in whole-body glucose utilization. Thus, we studied in vivo insulin sensitivity by the insulin tolerance test (ITT) and we determined GLUT4 protein in WAT and SM by Western blotting. Additionally, we evaluated GLUT4 protein concerning its relative and absolute tissue and body contents.

\section{Material and Methods}

\section{Animals}

Male Wistar rats were individually caged in an environment maintained at $23 \pm 2^{\circ} \mathrm{C}$, on a 12:12-h light (6:00-18:00)-dark (18:006:00) cycle, and fed a standard rodent chow diet (pelleted Nuvilab CR-1, Nuvital, Curitiba, PR, Brazil). Animals were allowed free access to water and standard rodent chow until the age of 2 months or 12 months (obese) when they were used for the experiments. An additional group of 12-month-old lean rats was obtained by subjecting animals to energy restriction during the previous month of life. During this period, animals were fed daily, receiving half of the food ingested by 12 -month-old obese rats, with a consequent $\sim 20 \%$ weight loss.

All experiments were carried out on anesthetized rats $(40 \mathrm{mg} / \mathrm{kg}$ body weight pentobarbital sodium), and the rats were studied at noon after $6 \mathrm{~h}$ of food deprivation. The experimental protocol was approved by the Ethics Committee for Animal Research of the Institute of Biomedical Sciences, University of São Paulo.

\section{Intravenous insulin tolerance test}

For estimation of in vivo insulin sensitivity, some animals from all groups were submitted to an intravenous (iv) ITT $(0.75 \mathrm{U} / \mathrm{kg}$ body weight) and samples for blood glucose determination were collected at 0 (basal), 4,8 , 12, 16, and 20 min after insulin injection. The ITT was performed through the jugular vein of anesthestized rats. Thereafter, the rate constant for plasma glucose disappearance (Kitt, \%/min) was calculated from the linear regression of the glucose concentration values from 0 to $20 \mathrm{~min}$ of the test, as described (17).

\section{Blood and tissue sampling}

Sacrifice was performed under anesthesia. Blood samples were obtained from the inferior vena cava and the serum was prepared and kept at $-20^{\circ} \mathrm{C}$ for further analysis. Periepididymal fat pad (WAT) and gastrocnemius muscle (SM) were removed, immediately weighed, frozen in liquid nitrogen, and stored at $-70^{\circ} \mathrm{C}$ for further analysis of GLUT4 protein expression. 


\section{Membrane preparation}

Three subcellular membrane fractions of WAT were prepared based on the method of Oka et al. (18) and modified as previously described $(18,19)$. Briefly, the tissues were homogenized using a Polytron (Brinkmann Instruments, Westbury, NY, USA) for $30 \mathrm{~s}$ at $4^{\circ} \mathrm{C}$ in $10 \mathrm{mmol} / 1 \mathrm{Tris}-\mathrm{HCl}, 1 \mathrm{mmol} / \mathrm{l}$ EDTA,

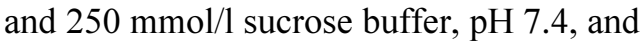
centrifuged at 3,000 $\mathrm{g}$ for $15 \mathrm{~min}$. Fat globules were discarded, and the volume of supernatant, a fat-free extract (FFE) fraction, was measured. One milliliter of FFE was kept for analysis, and the rest was centrifuged at $12,000 \mathrm{~g}$ for $15 \mathrm{~min}$. The pellet was resuspended as a plasma membrane (PM) fraction in $1 \mathrm{ml}$ of buffer. The supernatant was also centrifuged at $28,000 \mathrm{~g}$ for $15 \mathrm{~min}$, the pellet was discarded and the supernatant was centrifuged at $146,000 \mathrm{~g}$ for $75 \mathrm{~min}$. The final pellet was resuspended as a microsome (M) fraction in $1 \mathrm{ml}$ buffer. SM was homogenized in the same buffer, and centrifuged at $1,000 \mathrm{~g}$ for $10 \mathrm{~min}$. The supernatant was saved, the pellet was resuspended in $1 / 3$ of the initial volume, and centrifuged again at $1,000 \mathrm{~g}$ for $10 \mathrm{~min}$. The two supernatant solutions were mixed and submitted to centrifugation at $150,000 \mathrm{~g}$ for $75 \mathrm{~min}$. The final pellet was resuspended in $1 \mathrm{ml}$ of buffer as a total membrane (TM) fraction (19).

\section{Western blotting}

Immunoblotting was carried out as previously described (15). Briefly, equal amounts of membrane proteins were solubilized in Laemmli's sample buffer, subjected to SDSPAGE (10\%), and electrophoretically transferred to nitrocellulose. After blocking with bovine serum albumin in PBS, the nitrocellulose membranes were incubated with an anti-GLUT4 antiserum for $3 \mathrm{~h}$ at $37^{\circ} \mathrm{C}$. This antiserum has been successfully used for immunoblotting at 1:200 dilution $(13,15,18$ $20)$. The membranes were then washed five times, incubated with [ $\left.{ }^{125} \mathrm{I}\right]$-protein-A (Amersham Pharmacia Biotech, Little Chalfont, UK) for $2 \mathrm{~h}$ at room temperature, washed again, and exposed to X-ray film for 5 days. The autoradiographic blots were quantified by densitometry (Image Master $1 \mathrm{D}^{\circledR}$, Pharmacia Biotech, Uppsala, Sweden) and the results are reported as arbitrary units (AU).

\section{Analytical procedures}

Serum samples were assayed for glucose by the glucose oxidase method (Analisa, Belo Horizonte, MG, Brazil), for insulin by RIA (Coat-A-Count, Diagnostic Products Co., Los Angeles, CA, USA), and for albumin by bromocresol green staining (CELM, São Paulo, SP, Brazil). The total protein concentration of membrane samples was assayed by the method of Lowry et al. (21).

\section{Adipocyte analysis}

Other animals were used to obtain freshly isolated adipocytes by the collagenase method, for microscopic analysis as previously described (18). Cell diameter was measured and volume was calculated by considering adipocytes to be spherical. One hundred cells from each rat (5 rats/group) were analyzed. The cell weight was obtained considering the density of triolein.

\section{Data analysis}

All data are reported as means \pm SEM. GLUT4 was quantified in 5 to 8 different experiments, each containing different samples from all animal groups. The initial data obtained are reported as $\mathrm{AU} / \mu \mathrm{g}$ protein loaded into the electrophoresis apparatus. In WAT, taking into account the total protein yield and volume of PM and $\mathrm{M}$ fractions, the total tissue PM and M GLUT4 content was calculated and expressed as AU. The relative tissue contents of PM and M GLUT4 were calculated based on the total GLUT4 
content and considering the tissue weight (AU/g tissue) or the body weight [(AU/g body weight) $\mathrm{x}$ 100]. Cellular PM and $\mathrm{M}$ GLUT4 contents were obtained on the basis of cell number. These values were used to analyze both the PM GLUT4 content, expressed as unit of cellular surface area (AU/

Table 1. Characteristics of 2-month-old, 12-month-old obese, and 12-month-old lean rats.

\begin{tabular}{lccc}
\hline & 2-month-old & 12-month-old obese & 12-month-old lean \\
\hline Body weight $(\mathrm{g})$ & $183.8 \pm 5.1$ & $419.9 \pm 9.8^{*}$ & $343.0 \pm 8.8^{*+}$ \\
Lee's index $(\mathrm{x} 100)$ & $30.3 \pm 0.2$ & $31.0 \pm 0.2^{*}$ & $30.4 \pm 0.3$ \\
Serum glucose $(\mathrm{mmol} / \mathrm{l})$ & $9.3 \pm 0.6$ & $10.1 \pm 0.8$ & $8.7 \pm 0.5$ \\
Serum insulin $(\mu \mathrm{g} / \mathrm{l})$ & $3.15 \pm 0.40$ & $7.20 \pm 0.72^{*}$ & $3.85 \pm 0.37^{+}$ \\
Serum albumin $(\mathrm{g} / \mathrm{l})$ & $2.65 \pm 0.04$ & $2.77 \pm 0.08$ & $2.52 \pm 0.07$ \\
Kitt $(\% / \mathrm{min})$ & $2.28 \pm 0.15$ & $1.49 \pm 0.26^{*}$ & $2.63 \pm 0.27^{+}$
\end{tabular}

Data are reported as mean \pm SEM body weight and Lee's index for 14 to 17 rats, and serum glucose, insulin, albumin and Kitt (rate constant for plasma glucose disappearance during intravenous insulin tolerance test) for 8 to 16 rats. Lee's index $=$ body weight (g) 1/3/nasoanal length (cm).

$* \mathrm{P}<0.05$ compared to 2-month-old rats;

$+P<0.05$ compared to 12 -month-old obese rats (ANOVA, Student-Newman-Keuls post hoc test).

Table 2. Characteristics of insulin-sensitive tissues of 2-month-old, 12-month-old obese, and 12-month old lean rats.

\begin{tabular}{lccc}
\hline & 2-month-old & $\begin{array}{c}\text { 12-month-old } \\
\text { obese }\end{array}$ & $\begin{array}{c}\text { 12-month-old } \\
\text { lean }\end{array}$ \\
& & & \\
\hline $\begin{array}{l}\text { Absolute weight }(\mathrm{g}) \\
\text { WAT }\end{array}$ & $0.82 \pm 0.07$ & $8.21 \pm 1.13^{*}$ & $4.36 \pm 0.49^{*+}$ \\
SM & $1.02 \pm 0.03$ & $2.20 \pm 0.03^{*}$ & $1.91 \pm 0.05^{*+}$ \\
Relative weight $(\mathrm{g} / \mathrm{100} \mathrm{g}$ body weight) & & \\
$\quad$ WAT & $0.44 \pm 0.03$ & $1.96 \pm 0.27^{*}$ & $1.18 \pm 0.11^{*+}$ \\
SM & $0.556 \pm 0.008$ & $0.525 \pm 0.010$ & $0.560 \pm 0.012^{+}$ \\
Adipocyte volume $\left(\mu \mathrm{m}^{3}\right) \times 10^{-3}$ & $38.8 \pm 1.08$ & $289.4 \pm 33.1^{*}$ & $124.4 \pm 23.7^{*+}$ \\
& & & \\
Protein yield (mg/g tissue) & & & \\
WAT & & & \\
$\quad$ PM & $0.47 \pm 0.05$ & $0.18 \pm 0.02^{*}$ & $0.23 \pm 0.02^{*}$ \\
M & $0.37 \pm 0.04$ & $0.20 \pm 0.03^{*}$ & $0.33 \pm 0.07$ \\
SM & $6.10 \pm 0.50$ & $3.30 \pm 0.40^{*}$ & $3.30 \pm 0.70^{*}$
\end{tabular}

Data are reported as mean \pm SEM tissue weight for 14 to 17 rats, protein yield for 5 to 12 rats, and adipocyte volume for 5 animals (100 cells per animal were measured). WAT, periepididymal white adipose tissue; SM, skeletal muscle (gastrocnemius); PM, plasma membrane; $\mathrm{M}$, microsome.

$* \mathrm{P}<0.05$ compared to 2-month-old rats;

$+\mathrm{P}<0.05$ compared to 12 -month-old obese rats (ANOVA, Student-Newman-Keuls post hoc test). $\mu \mathrm{m}^{2}$ ), and the translocation index [cell PM GLUT4/(cell PM GLUT4 + cell M GLUT4) $x$ 100], and these data were also related to the insulinemia at the time of tissue removal. In SM, the total protein yield in the TM fraction was used to calculate the total tissue content of GLUT4 (AU) and the relative data were similarly obtained considering tissue and animal weights. Data were analyzed statistically by ANOVA followed by the Student-Newman-Keuls post hoc test when appropriate.

\section{Results}

The general characteristics of the animals are shown in Table 1. The 12-monthold obese rats were heavier than the 2-monthold control rats, and showed a higher Lee's index $(\mathrm{P}<0.001)$, demonstrating the presence of obesity. On the other hand, 12-monthold lean rats had an $\sim 20 \%$ lower $(\mathrm{P}<0.001)$ body weight than 12-month-old obese rats, without a difference in Lee's index. Although glycemia remained unchanged in all groups, insulinemia was over $100 \%$ higher $(\mathrm{P}<0.001)$ in 12-month-old obese rats, and loss of weight decreased $(\mathrm{P}<0.001)$ glycemia to that observed in the control group. The Kitt value was significantly lower in 12-month-old obese rats than in 2-month-old $(\mathrm{P}<0.01)$ and 12 -month-old lean $(\mathrm{P}<0.05)$ rats. Serum albumin was similar among groups, indicating that the food restriction schedule did not promote undernutrition in 12-month-old lean animals.

Table 2 shows the tissue characteristics of the different animal groups. The periepididymal fat pad weight of 12-month-old obese rats was 10 -fold $(\mathrm{P}<0.001)$ the value of 2 month-old rats, and the tissue weight relative to body weight was still 4 -fold $(\mathrm{P}<0.001)$ the value of 2-month-old rats. The loss of weight reduced these values, although they were still higher than the 2-month values. The gastrocnemius weight of 12-month-old obese rats was 2 -fold $(\mathrm{P}<0.001)$ the value of 2 - 
month-old rats, and this difference disappeared when the relative tissue weight was analyzed. The loss of weight reduced $(\mathrm{P}<0.001)$ the absolute SM weight and increased $(\mathrm{P}<0.01)$ the relative SM weight. The cell volume of 12-month-old obese rats was more than seven times $(\mathrm{P}<0.001)$ the value of 2 month-old rats, and the loss of weight reduced $(\mathrm{P}<0.001)$ the cell volume by $60 \%$, although this value was still higher $(\mathrm{P}<0.05)$ than the value of 2-month-old rats. Finally, the total protein yield in the membrane fractions, expressed as $\mathrm{mg}$ protein/g tissue, is shown in Table 2. In general, these values were lower $(\mathrm{P}<0.05$ to $\mathrm{P}<0.001)$ in 12-monthold obese rats, and the loss of weight increased $(\mathrm{P}<0.01)$ the protein yield only in the FFE of WAT.

GLUT4 protein in WAT, expressed as $\mu \mathrm{g}$ total protein subjected to electrophoresis, is shown in Figure 1. Compared to 2-monthold control rats, in all membrane fractions, the blot densities were lower in both 12 month-old obese and 12-month-old lean rats. Compared to 2-month-old rats, GLUT4 in FFE was reduced $(\mathrm{P}<0.08)$ by 65 and $73 \%$ in 12-month-old obese and 12-month-old lean rats, respectively. Similarly, in the PM fraction GLUT4 was reduced $(\mathrm{P}<0.05)$ by 64 and $68 \%$ in 12 -month-old obese and 12 month-old lean rats, respectively, and in the $\mathrm{M}$ fraction, GLUT4 was reduced by $45 \%$ $(\mathrm{P}<0.09)$ in 12-month-old obese rats and by $72 \%(\mathrm{P}<0.05)$ in 12 -month-old lean rats compared to 2-month-old rats. On the other hand, the GLUT4 protein in SM (Figure 2), expressed as $\mu \mathrm{g}$ total protein subjected to electrophoresis, was unchanged in all groups.

Different analyses of GLUT4 protein in WAT and SM are shown in Table 3. In WAT and SM, the total tissue GLUT4 content did not change among groups. However, the tissue GLUT4 protein content, expressed as $\mathrm{g}$ tissue weight, was reduced by $\sim 80 \%$ $(\mathrm{P}<0.001)$ in WAT and by $\sim 50 \%(\mathrm{P}<0.05)$ in SM from 12-month-old obese rats compared to 2-month-old rats, and the loss of weight did not significantly affect these contents, which remained lower than in 2-month-old rats. On the other hand, when expressed as $g$ body weight, the GLUT4 protein content in SM was similarly reduced $(\mathrm{P}<0.05)$ in 12 month-old obese and 12-month-old lean compared to 2-month-old rats, while in WAT these data did not differ among groups.

PM GLUT4 expressed per unit of adipocyte surface area (Figure 3) was 55\% lower $(\mathrm{P}<0.05)$ in 12 -month-old obese rats compared to 2-month-old rats, and the loss of weight increased this content by $20 \%$. How-
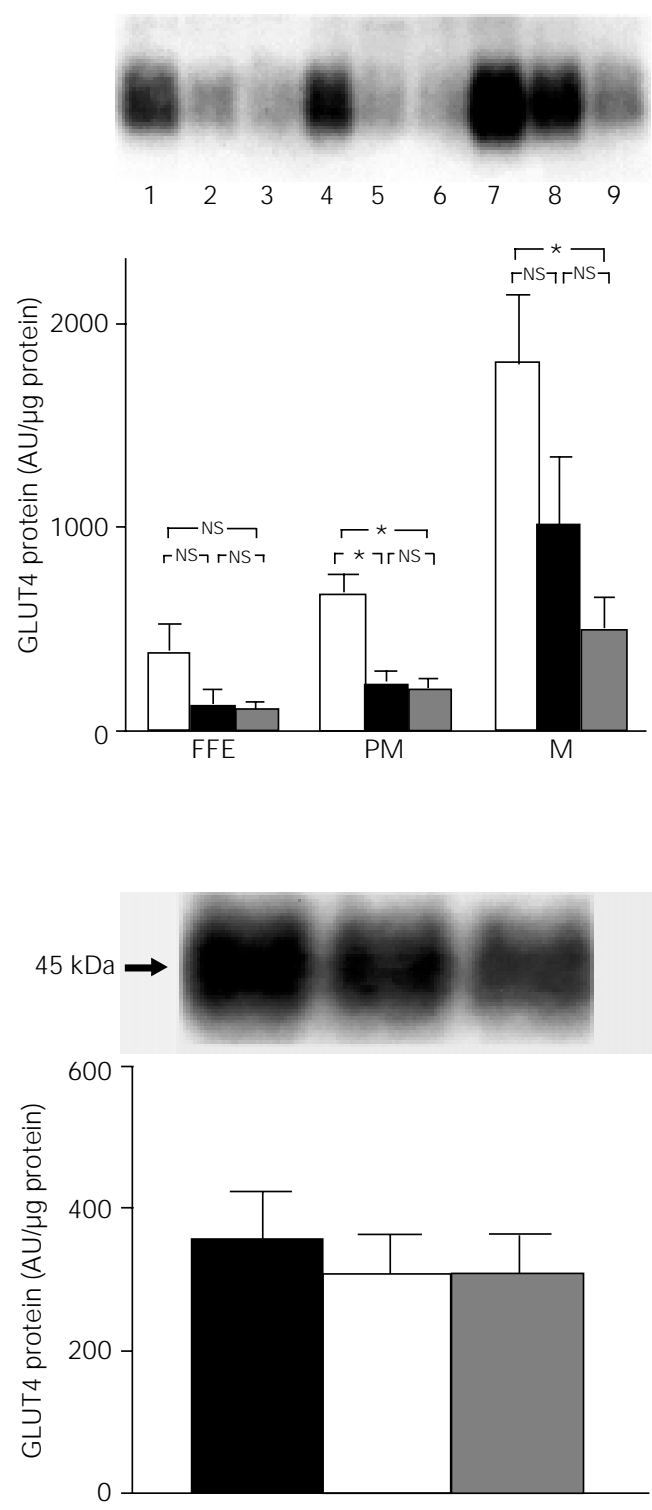

Figure 1. GLUT4 protein content of fat-free extract (FFE), plasma membrane (PM) and microsome (M) fractions of white adipose tissue from 2-month-old (white bars), 12-month-old obese (black bars), and 12-month-old lean (gray bars) rats. Equal amounts of protein were subjected to electrophoresis and immunoblotted as described in Material and Methods. Top, A typical autoradiogram is shown. Lanes 1 to 3 , FFE; 4 to $6, \mathrm{PM} ; 7$ to $9, \mathrm{M} ; 1,4$ and 7, 2-month-old rats; 2,5 and 8, 12-month-old obese rats; 3,6 and 9, 12-month-old lean rats. Bottom, Mean \pm SEM for 5 animals processed in 5 different experiments. $* P<0.05$ for the statistical comparisons indicated by the horizontal brackets (ANOVA, Student-Newman-Keuls posthoc test). AU, arbitrary units; NS, not significant.

Figure 2. GLUT4 protein content in total membrane fraction of skeletal gastrocnemius muscle from 2-month-old (black bar), 12month-old obese (white bar), and 12-month-old lean (gray bar) rats. Equal amounts of protein were subjected to electrophoresis and immunoblotted as described in Material and Methods. Top, A typical autoradiogram is shown. Bottom, Mean \pm SEM for 7 animals processed in 7 different experiments. $\mathrm{AU}$, arbitrary units. There were no significant differences between samples (ANOVA, Student-Newman-Keuls post hoc test). 
Table 3. GLUT4 protein content in white adipose tissue (WAT) and skeletal muscle (SM) of 2-month-old, 12-month-old obese, and 12-month-old lean rats.

\begin{tabular}{lccc}
\hline & 2-month-old & 12-month-old obese & 12-month-old lean \\
\hline $\begin{array}{l}\text { White adipose tissue } \\
\text { Total tissue GLUT4 }\end{array}$ & & & \\
$\quad$ PM & $248 \pm 28.4$ & $424 \pm 132$ & $256 \pm 69.7$ \\
$\quad$ M & $522 \pm 105$ & $1090 \pm 468$ & $812 \pm 263$ \\
GLUT4/g tissue & & & \\
PM & $311 \pm 51.6$ & $38.3 \pm 12.9^{*}$ & $58.5 \pm 17.2^{*}$ \\
M & $672 \pm 179$ & $164 \pm 61.9^{*}$ & $186 \pm 67.1^{*}$ \\
GLUT4/g body weight & & & \\
$\quad$ PM & $1.41 \pm 0.17$ & $1.03 \pm 0.26$ & $0.74 \pm 0.17$ \\
$\quad$ M & $3.04 \pm 0.51$ & $4.90 \pm 2.15$ & $2.36 \pm 0.81$ \\
Skeletal muscle & & & \\
$\quad \begin{array}{l}\text { Total tissue GLUT4 } \\
\text { GLUT4/g tissue }\end{array}$ & $2103 \pm 450$ & $2074 \pm 465$ & $1995 \pm 456$ \\
GLUT4/g body weight & $12.3 \pm 2.8$ & $4.9 \pm 1.0^{*}$ & $6.2 \pm 1.2^{*}$ \\
\hline
\end{tabular}

GLUT4 protein was determined in plasma membrane (PM) and microsome (M) fractions of WAT, and in the total membrane fraction of SM. The results are reported as total tissue content (AU), and relative content expressed as $g$ tissue (AU/g tissue) and as $g$ body weight (AU/g body weight $x$ 100). Data are reported as mean \pm SEM of 5-8 experiments.

*P $<0.05$ compared to 2-month-old rats (ANOVA, Student-Newman-Keuls post hoc test).
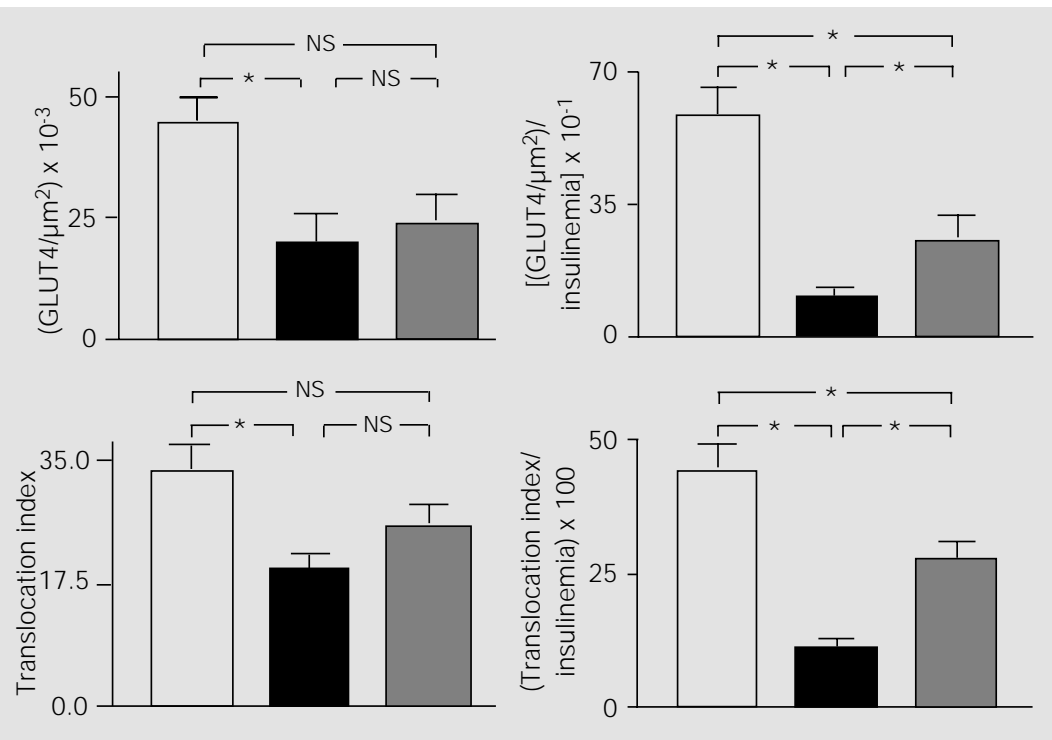

Figure 3. GLUT4 content in plasma membrane (PM) fraction of white adipose tissue from 2month-old (white bars), 12-month-old obese (black bars), and 12-month-old lean (gray bars) rats. PM GLUT4 is expressed per unit of cell surface area (upper left panel) and PM GLUT4 per unit of cell surface area relative to insulinemia at the time of tissue withdrawal (upper right panel). The translocation index [total PM GLUT4/(total PM GLUT4 + total microsome GLUT4) $\times 100$ ] is presented in the lower left panel and the translocation index relative to insulinemia at the time of tissue withdrawal is presented in the lower right panel. Data are reported as mean $\pm \mathrm{SEM}$ for $\mathrm{N}=5$ animals. $* \mathrm{P}<0.05$ for the statistical comparisons indicated by the horizontal brackets (ANOVA, Student-Newman-Keuls post hoc test). NS $=$ difference not statistically significant. ever, if we analyze PM GLUT4 expressed per unit of surface area relative to insulinemia at the time of tissue withdrawal, the value of 12 -month-old obese rats was strongly reduced $(\mathrm{P}<0.001)$ compared to 2-month-old rats and the weight loss increased $(\mathrm{P}<0.05)$ this parameter by $130 \%$, although it remained lower $(\mathrm{P}<0.01)$ than the 2 -month value. Figure 3 also shows the translocation index of GLUT4 at the time of tissue withdrawal, obtained from the analysis of PM GLUT4 content related to PM + M GLUT4 content. Compared to 2-month-old rats, the index was $40 \%$ lower $(\mathrm{P}<0.05)$ in 12 -month-old obese rats, and the loss of weight increased this value by $33 \%$. Additionally, when related to insulinemia, the weight loss promoted a $150 \%$ increase $(\mathrm{P}<0.05)$ in the translocation index.

\section{Discussion}

Recently, 12-month-old rats have been considered to be a very important model of obesity since obesity gradually develops with aging as a consequence of food availability and a sedentary life style $(11,22)$. This is similar to what is observed in humans, with some aged populations showing a very high prevalence of obesity (1). As rats continuously grow after maturity, obesity must be carefully analyzed in this model. The 12month-old obese rats cannot be considered obese only because of their increased body weight. However, they were obviously obese, judging from the increased Lee's index, heavier WAT, even relative to body weight, increased adipocyte volume, and reduced protein yield from WAT.

The energy restriction imposed on 12month-old obese rats in the present study produced a $20 \%$ reduction in body mass, with changes in tissue weight showing loss of fat mass, as expected. However, the WAT relative weight and adipocyte volume of 12month-old lean rats remained higher than the value of 2-month-old rats, indicating that the 
weight loss reduced obesity significantly but partially.

Hyperinsulinemia $(23,24)$ and increased adipocyte volume (25) have already been described in 12-month-old obese Wistar rats, in which obesity has been pointed out as the main factor responsible for physiopathological changes, since the loss of weight can reverse most of these alterations. We have previously observed abnormal response to $i v$ glucose tolerance test in 12-month-old obese rats compared to 2-month-old rats, despite hyperinsulinemia, and also an improvement in the $i v$ glucose tolerance test with a $20 \%$ weight loss (11). In the present study, the ITT confirmed the insulin resistant condition of 12-month-old obese rats as well as the improvement of the insulin sensitivity of 12-month-old lean rats. An inverse correlation between adipocyte volume and the ability of insulin to stimulate glucose transport (26) and metabolism (27) has already been reported, and amelioration of in vitro insulin sensitivity by weight loss has also been described in adipocytes isolated from 12-monthold obese rats $(26,27)$.

In the present study, a strong modulation in tissue GLUT4 protein content was detected in WAT and SM from 12-month-old obese rats, but the modulation changed according to the tissue and type of analysis.

In WAT, GLUT4 protein was reduced when determined per $\mu \mathrm{g}$ total protein loaded in the electrophoresis. The GLUT4 content of the PM and $\mathrm{M}$ fractions expressed as $\mathrm{g}$ tissue, as well as the PM GLUT4 expressed per unit of cell surface area, were also strongly reduced in 12-month-old obese rats, and this was definitely involved in the tissue/cell insulin resistance. Additionally, a reduction in the amount of GLUT4 translocated to PM was detected, and this amount, when related to the insulinemia, was reduced even more, suggesting that a damage in the translocation process may also be involved in cellular insulin resistance. In fact, studies of the insulin transduction signaling and the aging pro- cess in Wistar rats showed a reduction in tissue content of insulin receptor substrate-1 (IRS-1), insulin receptor phosphorylation, phosphatidylinositol 3-kinase and IRS-1 association, and IRS-2 phosphorylation (28). On the other hand, the GLUT4 content expressed as $\mathrm{g}$ body weight was not reduced and, consequently, the WAT may not play an important role in the reduced whole-body insulin resistance of obese rats. The reduced tissue/cell ability to take up glucose would be compensated for by the increased tissue mass, and, thus, the in vivo glucose clearance by WAT would be preserved.

Weight loss did not promote significant changes in GLUT4 protein content in WAT, suggesting no modulation in gene expression. However, both the PM GLUT4 content, expressed per unit of cell surface area, and the translocation index increased in 12-month-old lean rats, when related to their insulinemia, which suggests that GLUT4 translocation to the PM was improved by the weight loss. Obviously, the translocation index does not support the notion that additional effects of insulin on GLUT4 translocation were improved in 12-month-old lean rats, but it clearly shows that in the fed state, during which the WAT was removed, and despite lower insulinemia, the density of GLUT4 in PM was significantly increased and may have been involved in the improvement of insulin sensitivity observed with the loss of weight.

In contrast, in SM from 12-month-old obese rats the GLUT4 protein content, expressed as $\mu \mathrm{g}$ protein subjected to electrophoresis, was unchanged compared to 2-month-old rats. However, the transporter tissue content was reduced by $50 \%$ when expressed as $\mathrm{g}$ tissue, and was possibly involved in tissue insulin resistance, as reported for 2-deoxy-glucose uptake expressed as $\mathrm{ml}$ of intracellular water (16). As the gastrocnemius mass doubled from 2 to 12 months of age, it is obvious that the total tissue content of GLUT 4 was unchanged in 12-month-old obese rats. However, the amount of transporter relative to body weight 
was strongly reduced, indicating an important role of this tissue in the in vivo insulin resistance of 12-month-old obese rats. On the other hand, in SM of 12-month-old lean rats, the amount of transporter expressed as $\mu \mathrm{g}$ protein loaded in the electrophoresis, or relative to $g$ tissue also did not change, and this is in accordance with the unchanged basal 3-Omethylglucose uptake evaluated as g muscle tissue in calorie-restricted rats (29). However, the amount of transporter relative to body weight was weakly increased (26\%), a fact possibly involved in the improvement of glucose homeostasis in 12-month-old Wistar rats.

Reduction in the GLUT4 content of insulin-sensitive tissues has been reported in several models of genetically $(8,30-32)$ or pharmacologically $(13,15,19,23,33)$ treated obese animals. A reduction in GLUT4 content was also reported in 20-month-old rats (34), but was considered to be related to the aging process. However, the true role of the GLUT4 contribution in tissue/whole-body glucose utilization has shown contradictory results. Here we are reporting that the reduced glucose uptake reported in 12-month-old obese rats $(22,35)$, expressed as g tissue, involves a reduction in the amount of GLUT4, expressed as $\mathrm{g}$ tissue in WAT and SM. However, since the fat mass strongly increased, the role of WAT GLUT4 protein content in the in vivo glucose clearance seems to be unimportant. Thus, SM may play a key role in the in vivo insulin resistance of 12-month-old obese rats.

The present results show that the conflicting reports concerning the role of GLUT4 in altered insulin-sensitivity may be the consequence of different types of analysis. Most studies on glucose uptake show the wholebody uptake, expressed as $\mathrm{m}^{2}$ or $\mathrm{kg}(10,36$, 37 ), or the tissue uptake, expressed as $g$ tissue (7,36-39). These data cannot be related to GLUT4 protein expressed as $\mu \mathrm{g}$ total protein subjected to electrophoresis $(7,10,37$ 39), since strong morphostructural changes occurred, such as changes in total tissue protein yield or tissue and body mass.
Changes in the GLUT4 content induced by loss of weight have already been investigated in other animal models. In severely obese and insulin-resistant monosodium glutamatetreated mice, a $20 \%$ loss of weight induced by caloric restriction for one month reversed the insulin resistance and completely restored the GLUT4 content in all insulin-sensitive tissues (13). Differently, prolonged caloric restriction (60\% of ad libitum intake initiated at 14 weeks of age) enhanced insulin stimulation of glucose transport in epitrochlear muscles of 8month-old Fischer rats, regardless of unchanged GLUT4 content (35).

In the present study, weight loss increased insulin sensitivity possibly because of an increase in GLUT4 protein density in the plasma membrane from WAT, and of a weak increase in the total SM protein content in relation to body weight.

The present study shows that obesity and weight loss altered whole-body insulin sensitivity by means of a differential regulation of tissue GLUT4 protein content. In WAT, obesity decreased GLUT4 protein expression, but the total GLUT4 protein content relative to body weight remained preserved. Weight loss did not modify the total GLUT4 protein content, but increased the transporter translocation to the PM. In SM, although obesity did not change the GLUT4 protein expression, it reduced the total tissue GLUT4 protein content relative to body weight, and the weight loss did not change the GLUT4 protein content. The present study clearly establishes that the true role of WAT and SM GLUT4 protein content in in vivo insulin sensitivity must be determined considering the strong morphostructural changes of these tissues, in addition to gene expression modulation, which require different types of data analysis.

\section{Acknowledgments}

The authors would like to thank Dr. Adauri Brezolin for help with manuscript preparation. 


\section{References}

1. De Fronzo RA \& Ferranini E (1991). Insulin resistance: a multifaceted syndrome responsible for NIDDM, obesity, hypertension, dyslipidemia, and atherosclerotic cardiovascular disease. Diabetes Care, 14: 173-194.

2. Haffner SM, Valdez RA, Hazuda HP, Mitchell BD, Morales PA \& Stern MP (1992). Prospective analysis of the insulin-resistance syndrome (syndrome $\mathrm{X}$ ). Diabetes, 41: 715-722.

3. Berger J, Biswas C, Vicario PP, Strout HV, Saperstein R \& Pilch PF (1989). Decreased expression of the insulin-responsive glucose transporter in diabetes and fasting. Nature, 340: 70-72.

4. Kahn BB, Cushman SW \& Flier J S (1989). Regulation of glucose transporter-specific mRNA levels in rat adipose cells with fasting and refeeding. J ournal of Clinical Investigation, 83: 199-204.

5. Klip A, Tsakiridis T, Marette A \& Ortiz PA (1994). Regulation of expression of glucose transporters by glucose: a review of studies in vivo and in cell cultures. FASEB J ournal, 8: 43-53.

6. Sivitz W, DeSautel SL, Kayano T, Bell GI \& Pessin J E (1989). Regulation of glucose transporter messenger RNA in insulin-deficient states. Nature, 340: 72-74.

7. Houmard JA, Weider MD, Dolan PL, Leggett-Frazier N, Gavigan KE, Hickey $M S$, Tyndall GL, Zheng $D$, Alshami $A$ \& Dohm GL (1995). Skeletal muscle GLUT4 protein concentration and aging in humans. Diabetes, 44: 555-560.

8. Kahn BB \& Pedersen O (1992). Tissuespecific regulation of glucose transporters in different forms of obesity. Proceedings of the Society for Experimental Biology and Medicine, 200: 214-217.

9. Freidenberg GR, Reichart D, Olefsky J M $\&$ Henry RR (1988). Reversibility of defective adipocyte insulin receptor kinase activity. Effect of weight loss. J ournal of Clinical Investigation, 82: 1398-1406.

10. Friedman J E, Dohm GL, Leggett-Frazier N, Elton CW, Tapscott EB, Pories WP \& Caro J F (1992). Restoration of insulin responsiveness in skeletal muscle of morbidly obese patients after weight loss. J ournal of Clinical Investigation, 89: 701705.

11. Machado UF, Nogueira CR \& Carpinelli AR (1992). Obesity is the major cause of alterations in insulin secretion and calcium fluxes by isolated islets from aged rats. Physiology and Behavior, 52: 717-721.

12. Handberg A, Vaag A, Damsbo P, Beck-
Nielsen H \& Vinten J (1990). Expression of insulin regulatable glucose transporters in skeletal muscle from type 2 (noninsulin-dependent) diabetic patients. Diabetologia, 33: 625-627.

13. Papa PC, Seraphim PM \& Machado UF (1997). Loss of weight restores GLUT 4 content in insulin-sensitive tissues of monosodium glutamate-treated obese mice. International J ournal of Obesity, 21 : 1065-1070.

14. Pedersen $\mathrm{O}$, Bak J F, Anderson PH, Lund S, Moller DE, Flier J F \& Kahn BB (1990). Evidence against altered expression of GLUT1 or GLUT4 in skeletal muscle of patients with obesity or NIDDM. Diabetes, 39: 865-870.

15. Machado UF, Shimizu Y \& Saito M (1993). Decreased glucose transporter (GLUT 4) content in insulin-sensitive tissues of obese aurothioglucose- and monosodium glutamate-treated mice. Hormone and Metabolic Research, 25: 462-465.

16. Gulve EA, Henriksen EJ, Rodnick KJ , Youn J H \& Holloszy J O (1993). Glucose transporters and glucose transport in skeletal muscles of 1- to 25-mo-old rats. American J ournal of Physiology, 264: E319-E327.

17. Bonora $E$, Moghetti $P$, Zancanaro $C$, Gigolini M, Querena M, Cacciatoni V, Corgnati A \& Muggeo M (1989). Estimation of in vivo insulin action in man: comparison of insulin tolerance test with euglycemic and hyperglycemic glucose clamp studies. J ournal of Clinical Endocrinology and Metabolism, 68: 374-378.

18. Oka Y, Asano T, Shibasaki Y, Kasuga M, Kanazawa Y \& Takaku F (1988). Studies with antipeptide antibody suggest the presence of at least two types of glucose transporter in rat brain and adipocyte. J ournal of Biological Chemistry, 263: 13432-13439.

19. Machado UF, Shimizu Y \& Saito M (1994). Reduced content and preserved translocation of glucose transporter (GLUT 4) in white adipose tissue of obese mice. Physiology and Behavior, 55: 621-625.

20. Lima FB, Machado UF, Bartol I, Seraphim PM, Sumida DH, Moraes SMF, Hell NS, Okamoto MM, Saad MJ A, Carvalho CRO $\&$ Cipolla-Neto J (1998). Pinealectomy causes glucose intolerance and decreases adipose cell responsiveness to insulin in rats. American J ournal of Physiology, 28: E934-E1041.

21. Lowry OH, Rosembrough NJ , Farr AL \& Randal RJ (1951). Protein measurement with the Folin phenol reagent. J ournal of
Biological Chemistry, 193: 265-275.

22. Ezaki O, Fukuda N \& Itakura H (1990). Role of two types of glucose transporters in enlarged adipocytes from aged obese rats. Diabetes, 39: 1543-1549.

23. Narimiya N, Azhar S, Dolkas CB, Mondon CE, Sims C, Wright DW \& Reaven GM (1984). Insulin resistance in older rats. American J ournal of Physiology, 246: E397-E404.

24. Reaven EP \& Reaven GM (1981). Structure and function changes in the endocrine pancreas of aging rats with preference to the modulating effects of exercise and caloric restriction. J ournal of Clinical Investigation, 68: 75-84.

25. Zinder O, Arad R \& Shapiro B (1967). Effect of cell size on the metabolism of isolated fat cells. Israel J ournal of Medical Sciences, 3: 787-791.

26. Hissin PJ , Foley J E, Wardzala LJ , Karnieli E, Simpson IA, Salans LB \& Cushman SW (1982). Mechanism of insulin-resistant glucose transport activity in the enlarged adipose cell of the aged, obese rat. J ournal of Clinical Investigation, 70: 780-790.

27. Salans LB \& Dougherty J W (1971). The effect of insulin upon glucose metabolism by adipose cells of different size influence of cell lipid and protein content, age and nutritional state. J ournal of Clinical Investigation, 50: 1399-1409.

28. Carvalho CRO, Brenelli SL, Silva AC, Nunes AL, Velloso LA \& Saad MJ (1996). Effect of aging on insulin receptor, insulin receptor substrate-1, and phosphatidylinositol 3-kinase in liver and muscle of rats. Endocrinology, 137: 151-159.

29. Dean DJ , Brozinick-J rJ T, Cushman J RSW \& Cartee GD (1998). Calorie restriction increases cell surface GLUT-4 in insulinstimulated skeletal muscle. American J ournal of Physiology, 275: E957-E964.

30. Hainault I, Guerre-Milo M, Guichard C \& Lavau M (1991). Differential regulation of adipose tissue glucose transporters in genetic obesity (fatty rat). J ournal of Clinical Investigation, 87: 1127-1131.

31. Koranyi L, J ames D, Mueckler $M \&$ \& Permutt MA (1990). Glucose transporter levels in spontaneously obese $(\mathrm{db} / \mathrm{db})$ insulin resistant mice. J ournal of Clinical Investigation, 85: 962-967.

32. Seino $Y$, Yamamoto $T \&$ Koh G (1992). Insulin and glucose transporter gene expression in obesity and diabetes. Proceedings of the Society for Experimental Biology and Medicine, 200: 210-213.

33. Le Marchand-Brustel $Y$, Olichon-Berthe $C$ 
Gremeaux T, Tanti J F, Rochet N \& Van Obbergen E (1990). Glucose transporter in insulin sensitive tissues of lean and obese mice. Effect of the thermogenic agent BRL 26830A. Endocrinology, 127: 2687-2695.

34. Lin J L, Asano T, Shibasaki Y, Tsukuda K, Katagiri H, Takaku F \& Oka Y (1991). Altered expression of glucose transporter isoforms with aging in rats - selective decrease in GLUT4 in the fat tissue and skeletal muscle. Diabetologia, 34: 477482.

35. Cartee GD, Kietzke EW \& Briggs-Tung C
(1994). Adaptation of muscle glucose transport with caloric restriction in adult, middle-aged, and old rats. American J ournal of Physiology, 266: R1443-R1447.

36. Escriva $F$, Agote $M$, Rubio E, Molero J C, Pascual-Leone AM, Andrés A, Satrustegui J \& Carrascosa J M (1997). In vivo insulindependent glucose uptake of specific tissues is decreased during aging of mature Wistar rats. Endocrinology, 138: 49-54.

37. Klip A \& Marette A (1992). Acute and chronic signals controlling glucose transport in skeletal muscle. J ournal of Cellular Biochemistry, 48: 51-60.
38. Kraegen EW, Sowden J A, Halstead MB, Clark PW, Rodnick KJ, Chisholm DJ \& J ames DE (1993). Glucose transporters and in vivo glucose uptake in skeletal and cardiac muscle: fasting, insulin stimulation and immunoisolation studies of GLUT1 and GLUT4. Biochemical J ournal, 295: 287-293.

39. Megeney LA, Neufer PD, Dohm GL, Tan $\mathrm{MH}$, Blewett CA, Elder GCB \& Bonen A (1993). Effects of muscle activity and fiber composition on glucose transport and GLUT4. American J ournal of Physiology, 264: E583-E593. 